Article

\title{
Towards Understanding the Role of Surface Gas Nanostructures: Effect of Temperature Difference Pretreatment on Wetting and Flotation of Sulfide Minerals and $\mathrm{Pb}-\mathrm{Zn}$ Ore
}

\author{
Yuri Mikhlin *(D), Anton Karacharov, Sergey Vorobyev $®$, Alexander Romanchenko®, \\ Maxim Likhatski, Svetlana Antsiferova and Svetlana Markosyan \\ Institute of Chemistry and Chemical Technology, Krasnoyarsk Science Center of the Siberian Branch of the \\ Russian Academy of Sciences, Akademgorodok, 50/24, 660036 Krasnoyarsk, Russia; karacharov@icct.ru (A.K.); \\ yekspatz@ya.ru (S.V.); romaas82@mail.ru (A.R.); lixmax@icct.ru (M.L.); sveta_a@icct.ru (S.A.); \\ obog@icct.ru (S.M.) \\ * Correspondence: yumikh@icct.ru
}

Received: 25 May 2020; Accepted: 9 July 2020; Published: 12 July 2020

\begin{abstract}
Surface nanobubbles at hydrophobic interfaces now attract much attention in various fields but their role in wetting-related phenomena is still unclear. Herein, we report the effect of a preliminary contact of "hot" solids with cold water previously proposed for generation of surface nanobubbles, on wettability of compact materials and flotation of particulate galena (PbS), sphalerite $(\mathrm{ZnS})$, and $\mathrm{Pb}-\mathrm{Zn}$ sulfide ore. Atomic force microscopy was applied to visualize the nanobubbles at galena crystals heated in air and contacted with cold water; X-ray photoelectron spectroscopy was used to characterize the surface composition of minerals. Contact angles measured with the sessile drop of cold water were found to increase when enhancing the support temperature from 0 to $80^{\circ} \mathrm{C}$ for sphalerite and silica, and to pass a maximum at $40-60^{\circ} \mathrm{C}$ for galena and pyrite $\left(\mathrm{FeS}_{2}\right)$ probably due to oxidation of sulfides. The temperature pretreatment depressed the recovery of sulfides in collectorless schemes and improved the potassium butyl xanthate-assisted flotation both for single minerals and Gorevskoye $\mathrm{Pb}-\mathrm{Zn}$ ore. The results suggest that the surface nanobubbles prepared using the temperature difference promote flotation if minerals are rather hydrophobic and insignificantly oxidized, so the addition of collector and activator (for sphalerite) is necessary.
\end{abstract}

Keywords: surface nanobubbles; hydrophobicity; oxidation; flotation; lead sulfide; zinc sulfide; $\mathrm{Pb}-\mathrm{Zn}$ ore

\section{Introduction}

Nanoscale surface gas-like structures, which often, but not exclusively, have the shape of a spherical segment and are referred to as "nanobubbles", attract a great deal of attention in recent years. These species are believed to be ubiquitous on hydrophobic surfaces and crucially influence many properties of solid/aqueous interfaces [1-6], being, for example, in many cases responsible for long-range capillary attraction (so-called hydrophobic forces) [7-12]. The mechanisms of formation and unusual stability, characteristics of the nanobubbles and their role in wetting, reactivity and other processes on the interfaces are insufficiently understood. Up to now, the overwhelming majority of studies have been performed using a solvent exchange technique for the nanobubble preparation (a sample is conditioned in ethanol and then in water). Atomically smooth highly oriented pyrolytic graphite (HOPG) is commonly used as a support, and atomic force microscopy and spectroscopy (AFM/AFS) in water is 
utilized for visualization and examination of nanobubbles (see, for example [3-6]). Employing these techniques, however, seems difficult or impossible for real materials, especially particulate ones.

One should expect that nanoscale gas domains can arise in hydrophobic minerals and affect their behavior in nature and mineral processing; first of all, particle-bubble interaction in air-saturated froth flotation slurries [13-17]. However, only in few works the nanobubbles have been detected experimentally under conditions related to the flotation processes. Hampton and Nguyen [16] have discussed a potential role of gaseous domains accumulated at the interface of graphite and aqueous solutions for froth flotation of coal; the common AFM and solvent exchange methods on HOPG were used in the experiments. Mikhlin et al. [18] found surface nanobubbles on HOPG and galena (PbS) pre-treated with potassium butyl xanthate solution using AFM/AFS, that for the first time involved a real mineral and flotation collector. Moreover, quasi in situ X-ray photoelectron spectroscopy (XPS) studies of the particulate sulfide minerals reacted with xanthate in the slurries, centrifuged and then fast-frozen $[19,20]$, revealed charging effects attributed to cavities separating the hydrophobized mineral particles which may be signatures of gas structures arising on the surfaces under the flotation-related conditions. Owens and co-workers [21,22] have imaged, with non-contact atomic force microscopy, surface nanobubbles on polished cross sections of dolomite and rare earth fluorcarbonate mineral synchysite treated with flotation collectors inducing hydrophobicity of the minerals. Xing et al. [23] have surveyed the hydrophobic force in particle-bubble attachment and concluded that the role of nanobubbles still remains to be identified.

Several researchers proposed a temperature difference (TD) method to produce nanobubbles [5,24-26]. In particular, An et al. [26] have reported a technique for simple and reproducible preparation of surface nanobubbles stable for several days without additional solvents and reagents by depositing cold water (e.g., $4{ }^{\circ} \mathrm{C}$ ) on HOPG substrates heated to $40-80{ }^{\circ} \mathrm{C}$. The nucleation of nanobubbles is caused by a lower solubility of gases in the heated water layer closest to the hot substrate than in bulk water. In the current research, we applied this method for generation of surface nanobubbles on galena $(\mathrm{PbS})$ and sphalerite $(\mathrm{ZnS})$ including particulate minerals and a $\mathrm{Pb}$ - $\mathrm{Zn}$ sulfide ore in order to elucidate the influence of the temperature difference between the "hot" solid and "cold" water and tentative surface gas domains on hydrophobicity and flotation of the minerals. Such a study is also of interest for understanding the mechanisms behind the wetting behavior of material surfaces and coatings in many other applications.

\section{Materials and Methods}

\subsection{Materials}

Single crystals of natural galena (Taymyr, Russia) were obtained from Geological Museum of Central Siberia (Krasnoyarsk, Russia); fresh fractured surfaces of about $3 \mathrm{~mm} \times 4 \mathrm{~mm}$ of the mineral were employed in AFM experiments, as described in detail elsewhere [16,23]. HOPG specimens (ZYH grade) purchased from NT-MDT (Russia) were cleaved directly before experiments. Galena (Gorevskoye deposit, Russia, or Zhairem ore deposit, Kazakhstan) and sphalerite with Fe $2.1 \mathrm{wt} . \%$ (Zhairem ore deposit, Kazakhstan) with no visible inclusions of foreign phases used. The mineral plates about $4 \mathrm{~mm} \times 5 \mathrm{~mm}$ were abraded using $\mathrm{SiC}$ paper (500 grit) and then wiped with wet filter paper and rinsed with water in the contact angle measurement. The minerals were ground in an agate mortar and sieved on standard wire mesh sieves to obtain the fraction less than $75 \mu \mathrm{m}$ and larger than $44 \mu \mathrm{m}(-75+44 \mu \mathrm{m})$ about $2 \mathrm{~h}$ before the microflotation experiments.

$\mathrm{Pb}-\mathrm{Zn}$ sulfide ore from Gorevskoye deposit (Krasnoyarsk Territory, Russia) had an average elemental composition, wt.\%: Pb 4.4, Zn 2.87, Fe 27.9, S 4.3, Si 5.5, Ca 1.0, Mg 1.0, O 42.2. The main sulfide minerals are galena, pyrrhotite $\left(\mathrm{Fe}_{7} \mathrm{~S}_{8}\right)$, sphalerite, pyrite; gangue minerals are presented by siderite $\left(\mathrm{FeCO}_{3}\right)$, quartz, dolomite $\left((\mathrm{Mg}, \mathrm{Ca}) \mathrm{CO}_{3}\right)$, calcite $\left(\mathrm{CaCO}_{3}\right)$, and some others. Ore samples were ground in a steel ball mill to $85 \%$ finer than $75 \mu \mathrm{m}$ at a solid/water/balls weight ratio of 1:0.5:9; some characteristics of the ground ore were reported earlier [24]. Then the solid and liquid phases were 
separated and heated or cooled in air to the temperatures ranged from 0 to $60{ }^{\circ} \mathrm{C}$ as described below (see also Supplementary Materials).

Commercial potassium n-butyl xanthate (KBX) of about $95 \%$ purity was recrystallized in acetone and then stored in solid state at $0{ }^{\circ} \mathrm{C}$; aqueous solutions of $\mathrm{KBX}$ were prepared before the experiments using deionized water. Other chemicals were of analytical grade and were used as received. Deionized water (Millipore Milli-Q grade) was used to prepare all the solutions. No plastic syringes, tubing, and so forth were utilized for handling the solutions and samples to avoid possible contamination.

\subsection{AFM and XPS Characterization}

Atomic force microscopy experiments were carried out using a multimode scanning probe microscope Solver P47 equipped with a piezoelectric tube scanner (NT-MDT, Moscow, Russia) having the nominal lateral resolution of about $0.1 \mathrm{~nm}$. In the study of the temperature difference, galena or HOPG substrates were fastened at a sapphire plate, and heated to the temperature ranging from 30 to $80^{\circ} \mathrm{C}$ in air. In a series of experiments, the mineral was preliminarily conditioned in $0.1 \mathrm{mM}$ or $10 \mathrm{mM} \mathrm{KBX}$ solutions for $10 \mathrm{~min}$ at room temperature and rinsed with water. The sample was placed in an open liquid Ti cell, and the cell was filled with deionized water $(1 \mathrm{~mL}, \mathrm{pH} 5.1)$ or the solution of $\mathrm{KBX}$ cooled to a temperature from 0 to $10^{\circ} \mathrm{C}$, and allowed to equilibrate for about $30 \mathrm{~min}$; AFM measurements were conducted after the aqueous phase reached room temperature. AFM images were obtained in the tapping mode (TM-AFM) with rectangular Si cantilever NSG11 (NT-MDT) with the nominal tip diameter of $10 \mathrm{~nm}$, the resonance frequency of about $110 \mathrm{kHz}$ in water and $150 \mathrm{kHz}$ in air and the spring constant of $\sim 10 \mathrm{~N} / \mathrm{m}$. The scan rate was $1-2 \mathrm{~Hz}$; no smoothing was applied. The images were obtained at least in 3-4 points for each sample; typically, 3 parallel samples were examined to ensure the reproducibility.

The state of mineral surfaces, including fractured, polished, and particulate single minerals and $\mathrm{Pb}-\mathrm{Zn}$ sulfide ores, were characterized using X-ray photoelectron spectroscopy. The spectra presented here were measured with a SPECS spectrometer equipped with a PHOIBOS 150 MCD-9 analyzer (SPECS, Berlin, Germany) at an electron take-off angle of $90^{\circ}$ employing $\mathrm{Mg} \mathrm{K} \alpha$ radiation (1253.6 eV) at room temperature. The analyzer pass energy was $20 \mathrm{eV}$ for survey spectra and $8 \mathrm{eV}$ for narrow scans. The $\mathrm{C} 1 \mathrm{~s}$ peak at $285.0 \mathrm{eV}$ from hydrocarbon contaminations was used as a reference. The surface concentrations of elements were determined employing the survey scans and the empirical sensitivity coefficients. The high resolution spectra were fitted with the Gaussian-Lorentzian peak profiles after the subtraction of the Shirley-type background using a CasaXPS software (version 2.3.16, Casa Software, Teignmouth, UK).

\subsection{Contact Angle Measurement}

Static contact angles reported here were measured using the sessile drop $(13 \mu \mathrm{L})$ with an OCA-15EC contact angle meter (DataPhysics Instruments, Filderstadt, Germany); the values reported are the average of at least 3 parallel sample measurements with the error within $\pm 2^{\circ}$. Deionized water or aqueous solutions of collectors were cooled down to $0.2{ }^{\circ} \mathrm{C}$ in the syringe and needle applying a cryo-thermostat, while a desired temperature of polished mineral plates of galena and sphalerite was set in the range from 0 to $80^{\circ} \mathrm{C}$ using an underlying Peltier element of a temperature unit TPC 160 (DataPhysics Instruments).

\subsection{Flotation Tests}

Flotation of single minerals was carried out utilizing $2 \mathrm{~g}$ of galena or sphalerite in each experiment in a modified Hallimond tube with air flow at approximately $50 \mathrm{~mL} / \mathrm{min}$. The minerals heated to $40{ }^{\circ} \mathrm{C}$ were agitated with icy water until reaching a room temperature (about $30 \mathrm{~min}$ ) followed by flotation (5 min) in water without collector or in $0.1 \mathrm{mM} \mathrm{KBX}$ solutions $(\mathrm{pH} 9)$ at ambient temperature. The flotation of sphalerite was also performed using $0.01 \mathrm{mM} \mathrm{CuSO}_{4}+0.1 \mathrm{mM} \mathrm{KBX}$ solution after the temperature difference pre-treatment. 
The experiments on flotation of the $\mathrm{Pb}-\mathrm{Zn}$ sulfide ore were carried out in a laboratory flotation impeller machine equipped with a $1000 \mathrm{~mL}$ cell. The slurry after the drum milling was separated by sedimentation and decantation to a solid residue and supernatant liquid, which were independently heated or cooled to desired temperatures, and mixed again before flotation. The slurry with the weight solid/water ratio of 1 to 5 equilibrated to room temperature was agitated in the cell (1200 rpm) with or without adding KBX collector and other reagents; the total flotation time was $11 \mathrm{~min}$. The flowsheets and reagent schemes based to those operating at Gorevskoye plant are described in detail in Supplementary Materials. The products were filtered, dried, and the concentration of elements was determined using X-ray fluorescent analysis with an Axios advanced Panalytical instrument (Panalytical BV, Almelo, The Netherlands). All the flotation experiments with minerals and the ore were repeated at least three times, with the average data presented.

\section{Results}

\subsection{Atomic Force Microscopy}

As almost all studies on the nanobubble formation, including the effect of TD, have been conducted with a HOPG substrate, and we first checked the applicability of our techniques on HOPG. Figure 1 shows the representative tapping mode AFM images (height and phase) acquired in room temperature water from HOPG that was heated before the contact with cold water. Species arising due to the TD treatment and well discernible both in the height and phase images had the lateral size of 100-300 $\mathrm{nm}$ and the height of 5-12 nm which agree with the dimensions of nanobubbles found by other authors [24-26] despite some differences in the AFM and sample preparation techniques. In particular, more rigid cantilevers used in the current research could affect apparent bubble dimensions [27]. We observed such nanobubbles in more than $50 \%$ of experiments. It seems possible that there also exist other gas structures on HOPG, including "pancakes" of 1-2 nm thick [2-6] and surface gas mono- and multi-layers [28], which are slightly visible (Figure 1, Sections 2 and 3; see also Figure S1 in Supplementary Materials) or may be invisible in the current experimental setup. On the other hand, submillimeter bubbles undetected with AFM but visible with an optical microscope or the naked eye develop with time at the pre-heated surfaces of HOPG and minerals in cold water, depending upon the temperature regime and pre-treatment with flotation collectors.
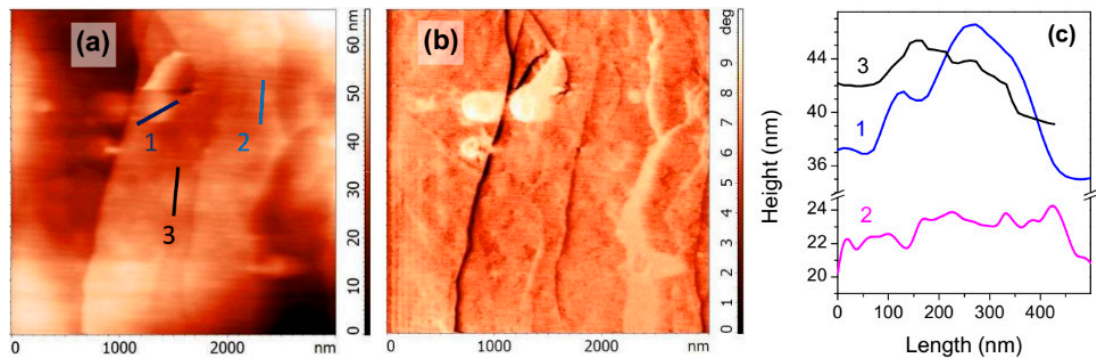

Figure 1. Tapping mode atomic force microscopy (AFM) height (a) and phase (b) images of highly oriented pyrolytic graphite (HOPG) surface heated to $60{ }^{\circ} \mathrm{C}$ and then conditioned in cold water $\left(5{ }^{\circ} \mathrm{C}\right)$ before AFM experiment in ambient water; (c) —height profiles along lines at (a) image.

Figure 2 shows AFM images collected in water from freshly fractured surface of galena (a, $a^{\prime}$, $\left.a^{\prime \prime}\right)$ and those preliminarily heated and then conditioned in cold water. The PbS surfaces are composed of terraces formed by crystal planes (100) and steps from atomic to several $\mathrm{nm}$ in the height. At the galena after the TD conditioning (Figure $\left.2\left(b, b^{\prime}, b^{\prime \prime}\right)\right)$, terraces are nanometer-scale rough due to the etch of PbS and oxidation products formed [18,29-33]. The larger entities are believed to be surface nanobubbles, which have the dimensions similar to those observed at HOPG (Figure 1). The nanobubbles previously found on galena reacted with butyl xanthate at room temperature had comparable lateral dimensions 
and 3-8 $\mathrm{nm}$ in height [18]. Neither such reaction products nor contaminations were detected using XPS (see below) and AFM [18,29] under comparable conditions.
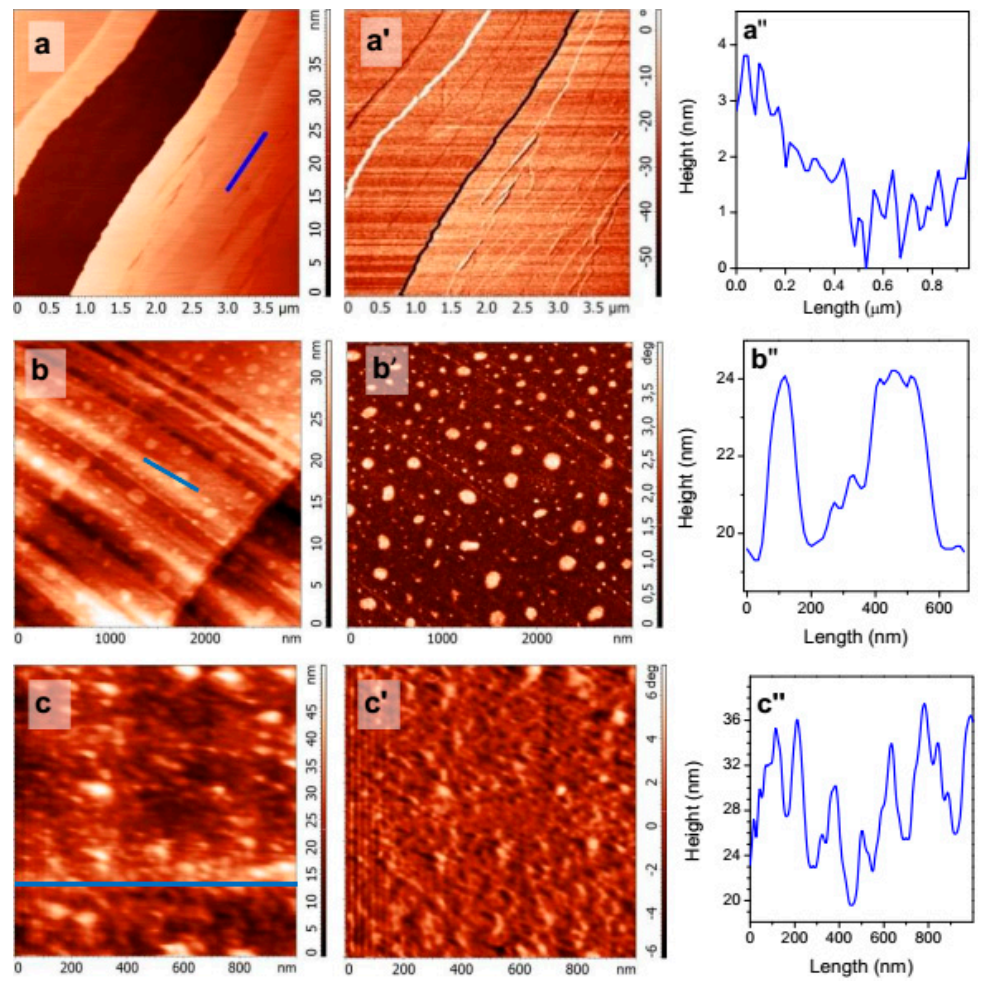

Figure 2. Tapping mode AFM images taken in ambient water from galena surfaces $\left(\mathbf{a}, \mathbf{a}^{\prime}\right)$ fractured, $\left(\mathbf{b}, \mathbf{b}^{\prime}\right)$ pre-treated using the temperature difference procedure in water (galena $(\mathrm{PbS})$ heated in air to $50{ }^{\circ} \mathrm{C}$ and then contacted with water cooled to $\left.5{ }^{\circ} \mathrm{C}\right) ;\left(\mathbf{c}, \mathbf{c}^{\prime}\right)$ heated at $50{ }^{\circ} \mathrm{C}$ and then reacted with cold $\left(5^{\circ} \mathrm{C}\right) 10 \mathrm{mM}$ potassium n-butyl xanthate $(\mathrm{KBX}) ;(\mathbf{a}-\mathbf{c})$ - height, $\left(\mathbf{a}^{\prime}-\mathbf{c}^{\prime}\right)$-phase contrast, $\left(\mathbf{a}^{\prime \prime}-\mathbf{c}^{\prime \prime}\right)$-relief profiles along the blue lines at the height images $(\mathbf{a}-\mathbf{c})$, respectively.

The results of AFM study on combined application of the TD and flotation collector KBX treatment are not conclusive because of $\mathrm{PbS}$ reactivity (oxidation) at elevated temperatures. Figure 2(c- $\left.\mathrm{c}^{\prime \prime}\right)$ represents characteristic AFM data for the surface of galena heated and then reacted with cold $10 \mathrm{mM}$ KBX solution prior the AFM experiment. The large number of species with the diameter of 50-200 nm and the height of 2-10 nm can be attributed to surface nanobubbles similar to those observed earlier but also to the products of oxidation of $\mathrm{PbS}$, mainly hydrophilic, and decomposition of xanthate, including lead xanthate [18,29-34]. Moreover, in some experiments we observed etch pits of 10-20 nm deep together with increased amount of surface reaction products (Figure S2).

The AFM study demonstrates, therefore, that the TD pretreatment does produce surface nanobubbles, which slightly differ from those formed as a result of the collector adsorption on $\mathrm{PbS}$ [18]. After application of both the TD and butyl xanthate treatment, the nanobubbles seem to coexist with the products of PbS reactions. It is important that the nanobubbles maintain after equilibrating the temperatures of galena and water. Nanobubbles were not surely specified in the experiments on sphalerite and pyrite, mostly because of their roughness as we avoided fine polishing and other procedures which may cause severe oxidation and distortion of the surfaces. A more detailed characterization of the gas structures was beyond the scope of this study.

\subsection{Contact Angle Measurement}

The impact of the temperature difference between a mineral and water, and so possible nanobubbles on surface hydrophobicity was studied using the sessile drop method. Figure 3 represents several 
examples of the water droplets cooled to $0.2{ }^{\circ} \mathrm{C}$ and placed on mineral plates kept at various temperatures, and summary of the average static contact angles. The data show that the wetting generally decreases, and the angles increase, with enhancing the temperature of solid supports. For galena, the contact angle grows as the substrate temperature increases to $40{ }^{\circ} \mathrm{C}$, and then decreases; the maximum persists for the mineral preliminarily hydrophobized with $10 \mathrm{mM} \mathrm{KBX}$ solution. Similar maxima at pyrite are shifted towards a higher temperature. The contact angle at more hydrophilic sphalerite steadily increases with temperature both for the mineral polished in air and that activated with aqueous copper sulfate before and after pre-conditioning in $10 \mathrm{mM} \mathrm{KBX}$ solution.

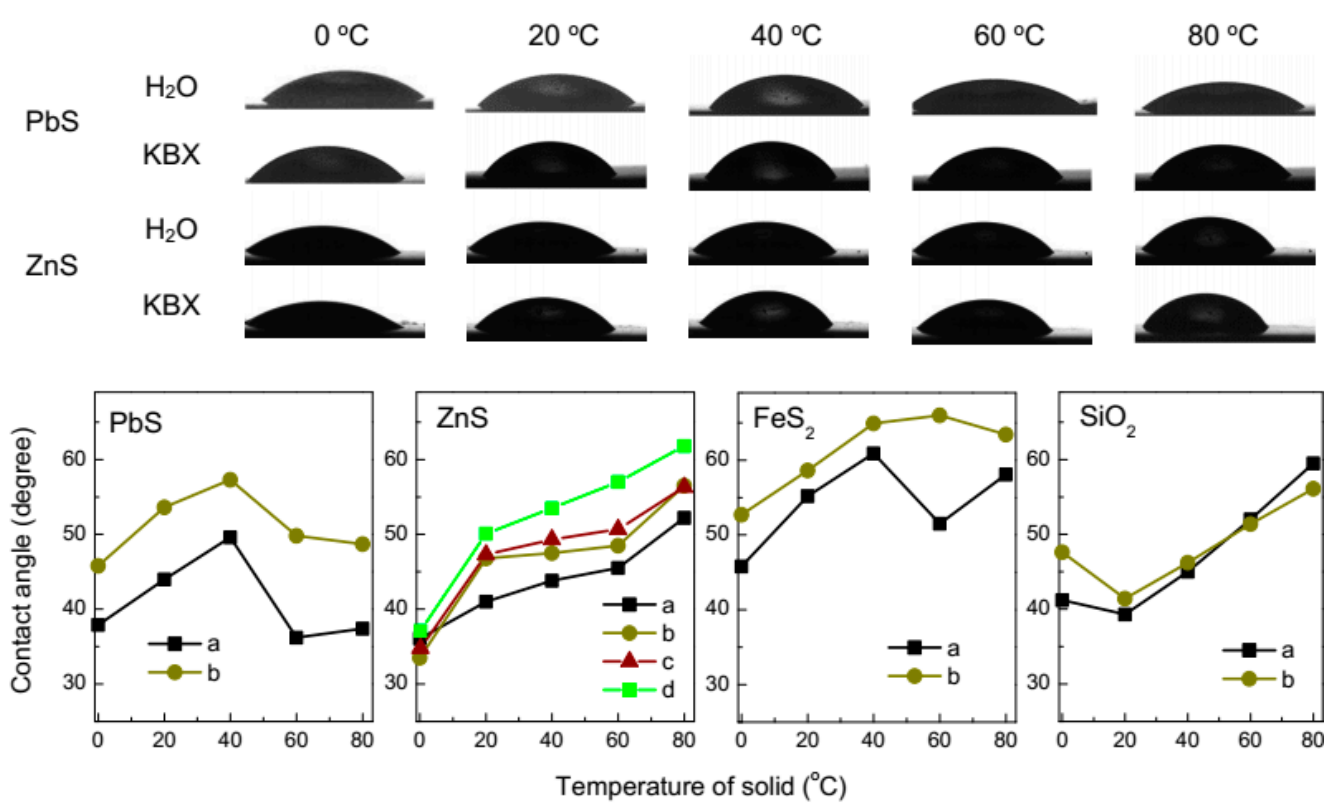

Figure 3. Upper panels: examples of sessile water drops cooled to $0.2{ }^{\circ} \mathrm{C}$ at galena and sphalerite plates kept at various temperatures. Lower panels: contact angles measured on the surfaces of $\mathrm{PbS}$, sphalerite ( $\mathrm{ZnS}$ ), $\mathrm{FeS}_{2}$ and $\mathrm{SiO}_{2}$ (oxidized $\mathrm{Si}$ ) plates as a function of the temperature of solid: (a) rinsed with water and $(\mathbf{b})$ reacted with $10 \mathrm{mM}$ potassium n-butyl xanthate solution (KBX) for $10 \mathrm{~min}$. ZnS was also preliminarily reacted with (c) $0.1 \mathrm{mM} \mathrm{CuSO}_{4}$ solution and then with $10 \mathrm{mM} \mathrm{KBX}(\mathbf{d})$.

The changes of wettability are unlikely to be due to temperature dependence of the surface tension $[35,36]$ and may be tentatively interpreted in terms of the formation of gas structures promoting hydrophobicity of sulfide minerals as their temperature increases. The effect competes with oxidation of sulfides, which makes them more hydrophilic, so the maxima at the plots can be explained by oxidation of galena and pyrite accelerated at higher temperatures [29-33,37-39]. This concurs with the behavior of sphalerite that is more resistant to oxidation, and silica becoming less hydrophilic with increasing temperature, while wetting of hydrophobic HOPG (not shown in figures) changes insignificantly. The surface tension of water decreasing with enhancing temperature may, however, contribute to higher wettability nearby $0{ }^{\circ} \mathrm{C}$ and above $40-50{ }^{\circ} \mathrm{C}$ for galena and pyrite.

\subsection{X-ray Photoelectron Spectroscopy Characterization}

The composition and chemical state of the surfaces of metal sulfides and ores was controlled using XPS analysis of the compact and particulate materials in various stages of the treatment. Figure 4 shows the spectra of the lead sulfide and zinc sulfide plates polished and washed with water as described in Section 2.1, and then utilized in contact angle measurements. The survey spectra confirm the absence of foreign phases, including conceivable Si-bearing lubricant contaminations from plastic cyringes, tubes, fittings, etc. [40], almost stoichiometric composition of $\mathrm{PbS}$ and $\mathrm{ZnS}$ surfaces, and negligible contents of impurity elements, excepting for Fe (about 2 at.\%) in sphalerite. The high-resolution $\mathrm{Pb} 4 \mathrm{f}$ and $\mathrm{Zn}$ 
$2 p$ spectra are characteristic of the metal sulfides [18-20,30,37,41] and indicative of low quantities of oxidized metal compounds; for example, the relative intensity of the $\mathrm{Pb}_{4} \mathrm{f}_{7 / 2}$ component at the binding energy (BE) of $138.8 \mathrm{eV}$ from lead oxide or/and hydroxide is as small as 4 rel.\%. The S 2p spectra are also typical for $\mathrm{PbS}$ and $\mathrm{ZnS}$, and show very minor contributions of disulfide and polysulfide anions (BEs of $162.2 \mathrm{eV}$ and $163.8 \mathrm{eV}$, respectively), and no S-O species at BEs above $166 \mathrm{eV}$; please note that the $\mathrm{S} 2 \mathrm{p}$ spectral region for $\mathrm{PbS}$ is overlapped with the secondary structure from $\mathrm{Pb} 4 \mathrm{f}$ maxima (plasmons, etc.). The $\mathrm{O} 1 \mathrm{~s}$ spectra of $\mathrm{PbS}$, which are somewhat different for galena and sphalerite, can be fitted using the peaks at $530.2 \mathrm{eV}$ (most likely, from minor surface $\mathrm{PbO}), 531.2 \mathrm{eV}\left(\mathrm{OH}^{-}\right.$groups), $532.7 \mathrm{eV}$ and $533.6 \mathrm{eV}$, attributable to adsorbed water or/and oxygen in adventitious carbonaceous contaminations. Similar maxima, shifted to higher BEs by $0.2-0.4 \mathrm{eV}$ probably because the Fermi level position in the bandgap of $\mathrm{ZnS}$, were found for sphalerite. The component at $531.5 \mathrm{eV}$ that likely originates from adsorbed $\mathrm{OH}^{-}$ions is, however, notably stronger than its counterpart for $\mathrm{PbS}$. This may be a reason for the lower hydrophobicity of sphalerite.
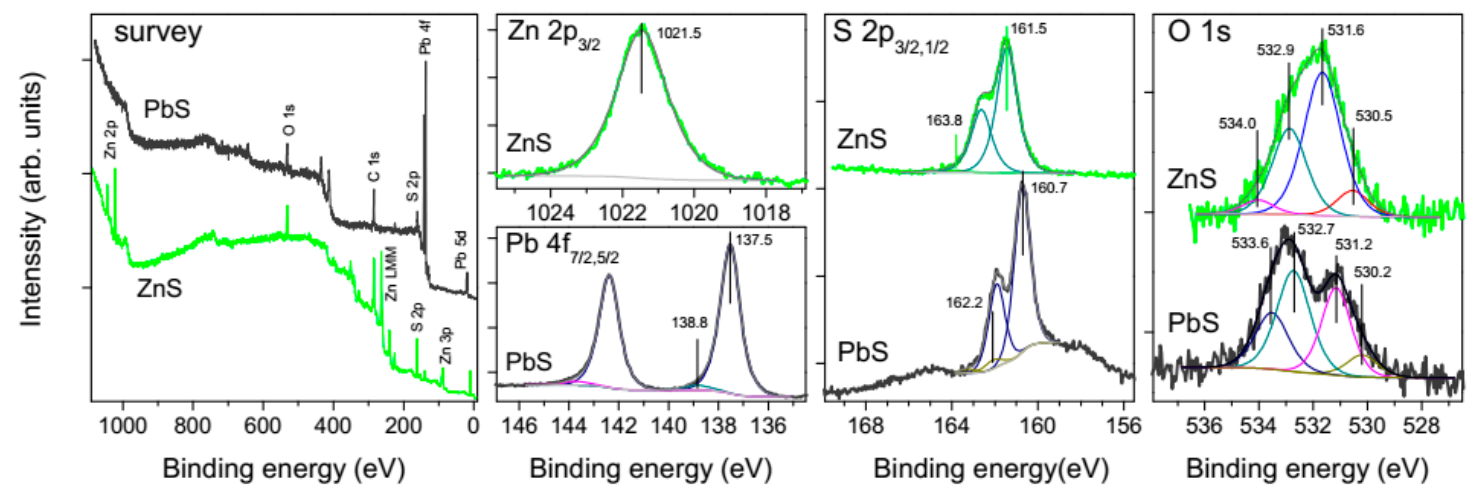

Figure 4. X-ray photoelectron spectra collected from polished and washed plates of natural $\mathrm{PbS}$ and $\mathrm{ZnS}$ used in the contact angle measurements.

The photoelectron spectra insignificantly altered after the treatments of the metal sulfides applied here, and are not shown in Figures. However, it should be taken in consideration that modification of the sulfide surfaces occurs ex situ upon handling the samples and XPS experiment in the ultra-high vacuum, including volatization of water, elemental sulfur, polysulfide anions, dixanthates, and decomposition of solid/water interface and some compounds. The species adsorbed due to the interaction with xanthate collector and other flotation reagents at particulate sulfide minerals $[18,19]$ and initial oxidation of chalcopyrite [42] were studied previously using low-temperature XPS of the fast-frozen specimens. We applied this method for examination of the oxidation of galena, sphalerite, and pyrite; the results to be published elsewhere. Application of the cryo-XPS for characterization of ground ores and compact materials is still problematic.

\subsection{Single Mineral Flotation}

Figure 5 shows the results of microflotation of galena and sphalerite in a Hallimond tube. The recovery under collectorless conditions somewhat decreased for galena and, slightly, for sphalerite preliminarily heated to $40^{\circ} \mathrm{C}$ and conditioned in cold water in comparison with the normal flotation at room temperature. Flotability of both minerals notably increased if collector $(0.1 \mathrm{mM} \mathrm{KBX})$ was added. In this case, the preliminary TD treatment exerted a small positive effect on the flotation of galena, and the recovery of sphalerite increased more notably. Flotation of sphalerite is further improved using the activation with copper ions, and TD procedure also shows a positive effect. The higher floatability after the pretreatment correlates with the enhanced hydrophobicity of the minerals (Figure 3) and may be due to surface nanobubbles arising at their surfaces (Figure 2), while the negative effect in the collectorless scheme may result from oxidation of sulfides after long contact with water [29-33,37]. 


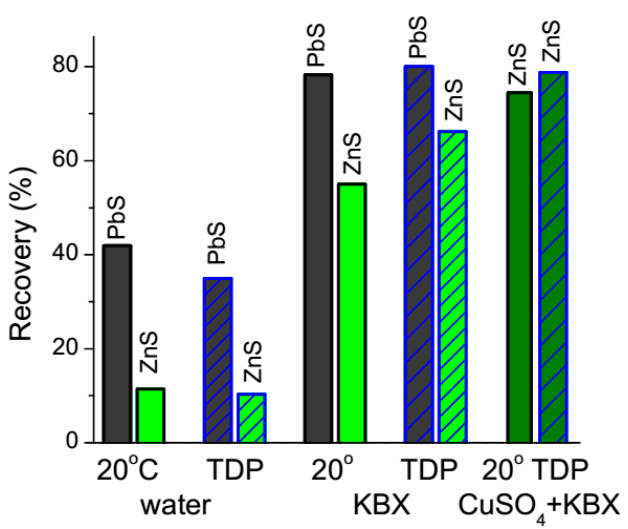

Figure 5. Flotation recoveries of $\mathrm{PbS}$ (galena) and $\mathrm{ZnS}$ (sphalerite) without (marked as $20^{\circ} \mathrm{C}$ ) and with the temperature difference pretreatment (TDP, solid heated to $40{ }^{\circ} \mathrm{C}$, water cooled to $2{ }^{\circ} \mathrm{C}$ ), with 0.1 $\mathrm{mM}$ KBX solution, and also with $0.02 \mathrm{mM} \mathrm{CuSO}_{4}$ and $0.1 \mathrm{mM} \mathrm{KBX}$ solution for sphalerite.

\subsection{Flotation of $\mathrm{Pb}-\mathrm{Zn}$ Sulfide Ore}

The experiments on bulk sulfide flotation of the $\mathrm{Pb}-\mathrm{Zn}$ ore, which separates hydrophobic sulfide minerals from ganguies, were conducted in a collectorless regime using "normal" mill products as a reference in comparison with the experiments in which the ground solid was heated to about $40^{\circ} \mathrm{C}$ and mixed with the aqueous phase cooled to $+5^{\circ} \mathrm{C}$ before the flotation; the residue was cooled and the liquid was heated up to $60^{\circ} \mathrm{C}$. Figure 6 shows (see also Tables S1-S5, Supplementary Materials) that the recovery of $\mathrm{Pb}$ increased after the ore treatment with hot water and decreased in the case of cold water. The floatability of sphalerite changed insignificantly. When sodium sulfide was added in order to suppress oxidation of metal sulfides (Figure 6a), we observed "normal" effect of the temperature difference, that is, the increased flotation of minerals preliminarily contacted with cold water. We believe that the oxidation of galena upon milling and heating play the main role, while hot water (and, in a smaller extent, sodium sulfide) removes hydrophilic fines and slimes [24,43] and oxidation products from the mineral surfaces.
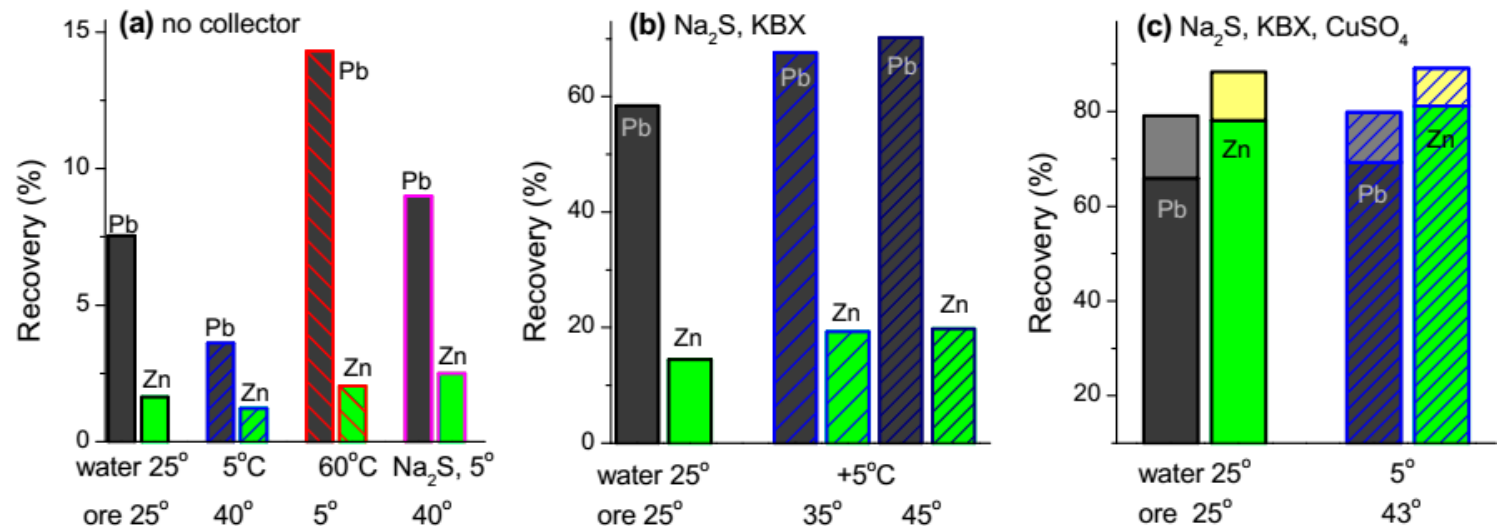

Figure 6. The results of bulk sulfide flotation (recoveries of $\mathrm{Pb}$ and $\mathrm{Zn}$ ) from Gorevskoye $\mathrm{Pb}-\mathrm{Zn}$ sulfide ore in various reagent scheme with and without the temperature difference pretreatment (the temperatures of aqueous phase and ore are shown at abscissa). (a) No collector added: no TD pre-treatment (both water and ore of about $25^{\circ} \mathrm{C}$ ); ore heated to $40{ }^{\circ} \mathrm{C}$, water cooled to $5^{\circ}$; ore cooled to $5^{\circ}$, water heated to $60{ }^{\circ} \mathrm{C} ; \mathrm{Na}_{2} \mathrm{~S}(100 \mathrm{~g} / \mathrm{t})$ added to the mill, ore heated to $40{ }^{\circ} \mathrm{C}$, water cooled to $5^{\circ}$. (b): $\mathrm{Na}_{2} \mathrm{~S}(100 \mathrm{~g} / \mathrm{t})$ and $\mathrm{Na}_{2} \mathrm{CO}_{3}(1000 \mathrm{~g} / \mathrm{t})$ were added to the mill, $\mathrm{KBX}(150 \mathrm{~g} / \mathrm{t})$ and frother T-92 $(50 \mathrm{~g} / \mathrm{t})$ was dosed to flotation cell $\left(\mathrm{pH} \mathrm{9.2,20}{ }^{\circ} \mathrm{C}\right)$, temperature pre-treatment regimes are shown at abscissa. (c) $\mathrm{Na}_{2} \mathrm{~S}(100 \mathrm{~g} / \mathrm{t})$ and $\mathrm{Na}_{2} \mathrm{CO}_{3}(2000 \mathrm{~g} / \mathrm{t})$ were added to the mill, KBX $(150 \mathrm{~g} / \mathrm{t})$, frother T-92 $(50 \mathrm{~g} / \mathrm{t})$ and $\mathrm{CuSO}_{4}(200 \mathrm{~g} / \mathrm{t})$ were dosed to the flotation cell, the upper parts of the columns show additional recoveries in one-step tail cleaning. 
Figure 7 presents photoelectron survey spectra and the spectra of lead acquired from the $\mathrm{Pb}-\mathrm{Zn}$ ore ground and then conditioned in $0.01 \mathrm{M} \mathrm{Na}_{2} \mathrm{~S}$ solution at room temperature or water at $60{ }^{\circ} \mathrm{C}$; the spectra of $S$ and other elements are not given to avoid confusion with the contributions of different minerals. One can see that the intensities of Fe and $\mathrm{O}$ lines (survey spectra) and maxima from lead oxide and hydroxide at the $\mathrm{Pb} 4 \mathrm{f}_{7 / 2}$ binding energy of $138.8 \mathrm{eV}$ somewhat decrease while PbS signal at $137.5 \mathrm{eV}$ increases (from 66 to 73 rel.\%) after the reactions with sulfide ions (spectra b). Moreover, the $\mathrm{Pb} 4 \mathrm{f}$ and S 2p spectra measured after the hot water treatment become about two times stronger, probably due to elimination of surface ultrafines [43], in agreement with the previous XPS studies on galena and Gorevskoye ore [29,30].
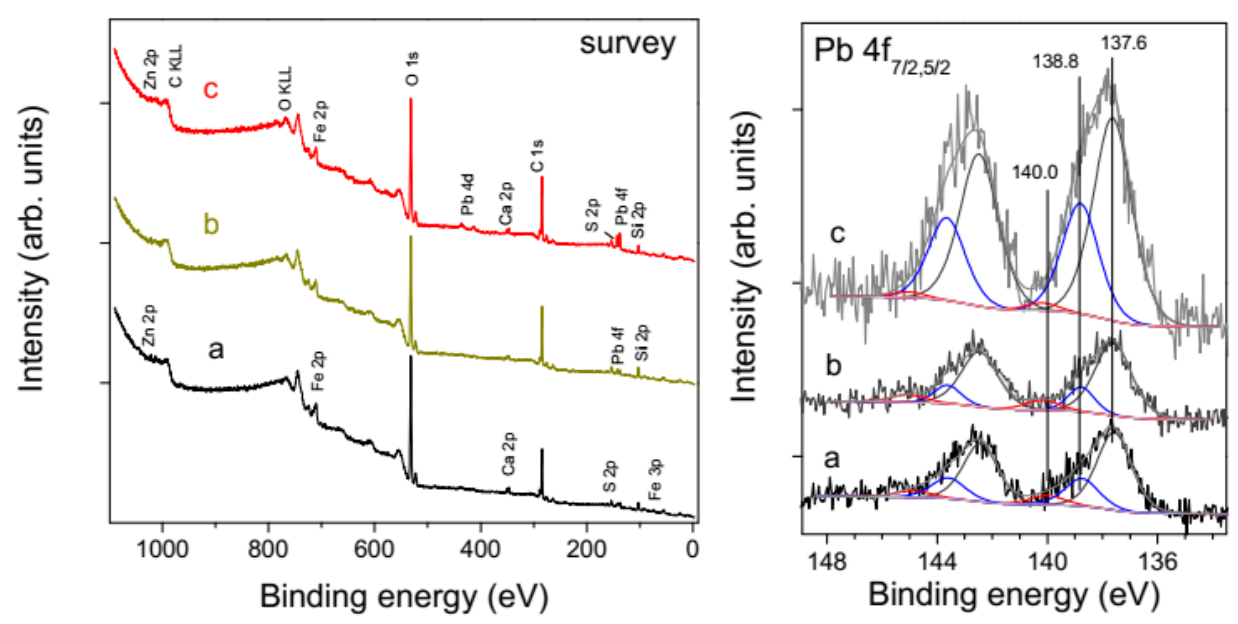

Figure 7. Photoelectron survey and $\mathrm{Pb} 4 \mathrm{f}$ spectra from (a) ground $\mathrm{Pb}-\mathrm{Zn}$ sulfide ore, (b) the ground ore treated with $0.1 \mathrm{M} \mathrm{Na}_{2} \mathrm{~S}$ solution $(10 \mathrm{~min}) ;(\mathrm{c})$ the ground ore treated with water heated to $60{ }^{\circ} \mathrm{C}$ (10 min).

The next series of tests were performed with adding KBX collector but without sphalerite activation with $\mathrm{CuSO}_{4}$; this increases the recovery of lead while that of zinc remains low. The preliminary heating the solid and cooling the aqueous phase essentially improve both the recovery of lead (from 58\% to about $70 \%$ ) and zinc (14.5\% to 19\%) and the quality of the bulk sulfide concentrate, with the contents of $\mathrm{Pb}$ and $\mathrm{Zn}$ growing from 31 to $40 \mathrm{wt}$ \%, and from 6 to $7 \mathrm{wt.} \%$, respectively (Supplementary Materials). At last, the bulk flotation experiments were carried out using the complete reagent scheme including addition of $\mathrm{CuSO}_{4}$ and frother T-92, and one-stage cleaning of the tails. The flotation of zinc sharply increased with the activator, and a positive effect of the temperature difference pre-conditioning ("hot" ore and cold water) was small but still observable both for lead and zinc recovery.

\section{Discussion}

This study demonstrated that the preliminary contact of "hot" metal sulfides and other solids with colder water promoted a generation of surface nanobubbles, and increased the hydrophobicity of solids and recovery of lead and zinc in froth flotation of the sulfide minerals and ores. The nanobubbles remain at the surfaces after the temperatures were equilibrated, in agreement with the findings reported previously for a model HOPG substrate [24-26]. The morphologies of the surfaces seem somewhat different from those formed due to the reaction with hydrophobizing $n$-butyl xanthate solutions [18] and combination of the TD and xanthate pretreatments.

The gas nanobubbles obtained with the temperature difference method do not ensure high enough hydrophobicity and floatability, and their effect is pronounced in the presence of butyl xanthate and other reagents. This suggests that the gas species are involved in the wetting and flotation processes in conjunction with other phenomena, particularly, oxidation of metal sulfides and adsorption of hydrophobizing agents, which control their hydrophilic/hydrophobic properties. We may hypothesize 
that the nanobubbles with larger height promote breakage of the interfacial water film upon collision of a mineral particle and an air bubble, while gas nanodomains covering a substantial surface area promote mineral surface hydrophobicity and subsequent spreading the solid/air interface, and so attachment of the particle to the large air bubble [19,44-46]. Some hints on this were found using AFM (Figures 1 and 2, and Refs. [18,21,22]) and cryo-XPS [19,20]. The formation of nanobubbles on essentially oxidized hydrophilic surfaces seems to be suppressed. It is also possible that the TD-induced gas nanobubbles on the surfaces with a considerable amount of oxidation products or/and ultrafine particles produced by grinding [30] form a sort of surface hydrophilic "foam" [47] which decreases the flotation. These phenomena shedding light on the fundamentals of wetting and hydrophobicity in various applications need to be studied in more detail.

It was found here that the flotation performance of the $\mathrm{Pb}-\mathrm{Zn}$ sulfide ore can be significantly improved imposing conditions favorable for the generation of surface nanobubbles in the system immediately related to the mineral engineering practice. Phase separation and heating the ore and cooling the large volumes of water are energy-consuming, and would unlikely be utilized at operating plants directly. However, these effects should be taken into consideration when handling heated milling products or circulating water, in particular, at Gorevskoye mill situated in a cold winter climate zone.

Supplementary Materials: The following are available online at http://www.mdpi.com/2079-4991/10/7/1362/s1, Figures S1 and S2: additional AFM images of HOPG and PbS surfaces. Figure S3: photographs of the sessile water droplets cooled to $0.2^{\circ} \mathrm{C}$ and placed on mineral plates, Figures S4 and S5: schemes of Gorevskoye Pb-Zn sulfide ore flotation in different regimes, Tables S1-S5: results of the bulk sulfide flotation of Gorevskoye Pb-Zn ore for different schemes.

Author Contributions: Supervision, conceptualization, investigation, writing, Y.M.; methodology, investigation, visualization, A.K., S.V., A.R., S.A., S.M., M.L. All authors have read and agreed to the published version of the manuscript.

Funding: This research was funded by Russian Science Foundation, grant number 18-17-00135.

Conflicts of Interest: The authors declare no conflict of interest. The funders had no role in the design of the study; in the collection, analyses, or interpretation of data; in the writing of the manuscript, or in the decision to publish the results.

\section{References}

1. Ishida, N.; Inoue, T.; Miyahara, M.; Higashitani, K. Nano bubbles on a hydrophobic surface in water observed by tapping-mode atomic force microscopy. Langmuir 2000, 16, 6377-6380. [CrossRef]

2. An, H.; Liu, G.; Craig, V.S.J. Wetting of nanophases: Nanobubbles, nanodroplets and micropancakes on hydrophobic surfaces. Adv. Colloid Interface Sci. 2015, 222, 9-17. [CrossRef] [PubMed]

3. Alheshibri, M.; Qian, J.; Jehannin, M.; Craig, V.S.J. A history of nanobubbles. Langmuir 2016, 32, 11086-11100. [CrossRef] [PubMed]

4. Zhang, X.; Lohse, D. Perspectives on surface nanobubbles. Biomicrofluidics 2014, 8, 041301. [CrossRef]

5. Lohse, D.; Zhang, X. Surface nanobubbles and nanodroplets. Rev. Mod. Phys. 2015, 87, 981-1035. [CrossRef]

6. Peng, H.; Hampton, M.A.; Nguyen, A.V. Nanobubbles do not sit alone at the solid-liquid interface. Langmuir 2013, 29, 6123-6130. [CrossRef]

7. Israelachvili, J.N.; Pashley, R.M. The hydrophobic interaction is long range, decaying exponentially with distance. Nature 1982, 300, 341-342. [CrossRef]

8. Meyer, E.E.; Rosenberg, K.J.; Israelachvili, J. Recent progress in understanding hydrophobic interactions. Proc. Natl. Acad. Sci. USA 2006, 103, 15739-15746. [CrossRef]

9. Cao, P.; Xu, K.; Varghese, J.O.; Heath, J.R. The microscopic structure of adsorbed water on hydrophobic surfaces under ambient conditions. Nano Lett. 2011, 11, 5581-5586. [CrossRef]

10. Tyrrell, J.W.G.; Attard, P. Atomic force microscope images of nanobubbles on a hydrophobic surface and corresponding force-separation data. Langmuir 2002, 18, 160-167. [CrossRef]

11. Attard, P. Nanobubbles and the hydrophobic attraction. Adv. Colloid Interface Sci. 2003, 104, 75-91. [CrossRef]

12. Hampton, M.A.; Nguyen, A.V. Nanobubbles and the nanobubble bridging capillary force. Adv. Colloid Interface Sci. 2010, 154, 30-55. [CrossRef] [PubMed] 
13. Yang, J.; Duan, J.; Fornasiero, D.; Ralston, J. Very small bubble formation at the solid-water interface. J. Phys. Chem. B 2003, 107, 6139-6147. [CrossRef]

14. Schubert, H. Nanobubbles, hydrophobic effect, heterocoagulation and hydrodynamics in flotation. Int. J. Miner. Process. 2005, 78, 11-21. [CrossRef]

15. Calgaroto, S.; Wilberg, K.Q.; Rubio, J. On the nanobubbles interfacial properties and future applications in flotation. Miner. Eng. 2014, 60, 33-40. [CrossRef]

16. Hampton, M.A.; Nguyen, A.V. Accumulation of dissolved gases at hydrophobic surfaces in water and sodium chloride solutions: Implications for coal flotation. Miner. Eng. 2009, 22, 786-792. [CrossRef]

17. Krasowska, M.; Malysa, K.; Beattie, D.A. Recent advances in studies of bubble-solid interactions and wetting film stability. Curr. Opin. Colloid Interface Sci. 2019, 44, 48-58. [CrossRef]

18. Mikhlin, Y.L.; Karacharov, A.A.; Likhatski, M.N. Effect of adsorption of butyl xanthate on galena, PbS, and HOPG surfaces as studied by atomic force microscopy and spectroscopy and XPS. Int. J. Miner. Process. 2015, 144, 81-89. [CrossRef]

19. Mikhlin, Y.; Karacharov, A.; Tomashevich, Y.; Shchukarev, A. Cryogenic XPS study of fast-frozen sulfide minerals: Flotation-related adsorption of n-butyl xanthate and beyond. J. Electron Spectrosc. Rel. Phenom. 2016, 206, 65-73. [CrossRef]

20. Mikhlin, Y.; Karacharov, A.; Tomashevich, Y.; Shchukarev, A. Interaction of sphalerite with potassium n-butyl xanthate and copper sulfate solutions studied by XPS of fast-frozen samples and zeta-potential measurement. Vacuum 2016, 125, 98-105. [CrossRef]

21. Owens, C.L.; Schach, E.; Rudolph, M.; Nash, G.R. Surface nanobubbles on the carbonate mineral dolomite. RSC Adv. 2018, 8, 35448-35452. [CrossRef]

22. Owens, C.L.; Schach, E.; Heinig, T.; Rudolph, M.; Nash, G.R. Surface nanobubbles on the rare earth fluorcarbonate mineral synchysite. J. Colloid Interface Sci. 2019, 552, 66-71. [CrossRef]

23. Xing, Y.; Gui, X.; Cao, Y. The hydrophobic force for bubble-particle attachment in flotation-A brief review. Phys. Chem. Chem. Phys. 2017, 19, 24421-24435. [CrossRef] [PubMed]

24. Guan, M.; Guo, W.; Gao, L.; Tang, Y.; Hu, J.; Dong, Y. Investigation on the temperature difference method for producing nanobubbles and their physical properties. ChemPhysChem 2012, 13, 2115-2118. [CrossRef] [PubMed]

25. Xu, C.; Peng, S.; Qiao, G.G.; Gutowski, V.; Lohse, D.; Zhang, X. Nanobubble formation on a warmer substrate. Soft Matter 2014, 10, 7857-7864. [CrossRef] [PubMed]

26. An, H.; Tan, B.H.; Zeng, Q.; Ohl, C.-D. Stability of nanobubbles formed at the interface between cold water and hot highly oriented pyrolytic graphite. Langmuir 2016, 32, 11212-11220. [CrossRef] [PubMed]

27. Walczyk, W.; Schön, P.M.; Schönherr, H. The effect of PeakForce tapping mode AFM imaging on the apparent shape of surface nanobubbles. J. Phys. Condens. Matter 2013, 25, 184005. [CrossRef]

28. Lu, Y.-H.; Yang, C.-W.; Fang, C.-K.; Ko, H.-C.; Hwang, I.-S. Interface-induced ordering of gas molecules confined in a small space. Sci. Rep. 2014, 4, 7189. [CrossRef]

29. Mikhlin, Y.L.; Romanchenko, A.S.; Shagaev, A.A. Scanning probe microscopy studies of PbS surfaces oxidized in air and etched in aqueous acid solutions. Appl. Surf. Sci. 2006, 252, 5645-5658. [CrossRef]

30. Mikhlin, Y.; Vorobyev, S.; Romanchenko, A.; Karasev, S.; Karacharov, A.; Zharkov, S. Ultrafine particles derived from mineral processing: A case study of the $\mathrm{Pb}-\mathrm{Zn}$ sulfide ore with emphasis on lead-bearing colloids. Chemosphere 2016, 147, 60-66. [CrossRef] [PubMed]

31. Kim, B.S.; Hayes, R.A.; Prestidge, C.A.; Ralston, J.; Smart, R.St.C. In-situ scanning tunnelling microscopy studies of galena surfaces under flotation-related conditions. Colloids Surf. Physicochem. Eng. Asp. 1996, 117, 117-129. [CrossRef]

32. Higgins, S.R.; Hamers, R.J. Spatially-resolved electrochemistry of the lead sulfide (galena) (001) surface by electrochemical scanning tunneling microscopy. Surf. Sci. 1995, 324, 263-281. [CrossRef]

33. De Giudici, G.; Rossi, A.; Fanfani, L.; Lattanzi, P. Mechanisms of galena dissolution in oxygen-saturated solutions: Evaluation of $\mathrm{pH}$ effect on apparent activation energies and mineral-water interface. Geochim. Cosmochim. Acta 2005, 69, 2321-2331. [CrossRef]

34. Vorobyev, S.; Saikova, S.; Novikova, S.; Fetisova, O.; Zharkov, S.; Krylov, A.; Likhatski, M.; Mikhlin, Y. Colloidal and immobilized nanoparticles of lead xanthates. ACS Omega 2019, 4, 11472-11480. [CrossRef] [PubMed] 
35. Bormashenko, E.Y. Wetting of Real Surfaces; Walter de Gruyter GmbH: Berlin, Germany; Boston, FL, USA, 2013; pp. 5-6.

36. Chau, T.T.; Bruckard, W.J.; Koh, P.T.L.; Nguyen, A.V. A review of factors that affect contact angle and implications for flotation practice. Adv. Colloid Interface Sci. 2009, 150, 106-115. [CrossRef] [PubMed]

37. Buckley, A.N.; Goh, S.W.; Lamb, R.N.; Woods, R. Interaction of thiol collectors with pre-oxidised sulfide minerals. Int. J. Miner. Process. 2003, 72, 163-174. [CrossRef]

38. Piantadosi, C.; Smart, R.St.C. Statistical comparison of hydrophobic and hydrophilic species on galena and pyrite particles in flotation concentrates and tails from ToF-SIMS evidence. Int. J. Miner. Process. 2002, 64, 43-54. [CrossRef]

39. Deng, M.; Karpuzov, D.; Liu, Q.; Xu, Z. Cryo-XPS study of xanthate adsorption on pyrite: Cryo-XPS study of xanthate adsorption on pyrite. Surf. Interface Anal. 2013, 45, 805-810. [CrossRef]

40. Wang, X.; Zhao, B.; Hu, J.; Wang, S.; Tai, R.; Gao, X.; Zhang, L. Interfacial gas nanobubbles or oil nanodroplets? Phys. Chem. Chem. Phys. 2017, 19, 1108-1114. [CrossRef]

41. Kartio, I.; Laajalehto, K.; Suoninen, E. Characterization of the ethyl xanthate adsorption layer on galena (PbS) by synchrotron radiation excited photoelectron spectroscopy. Colloids Surf. Physicochem. Eng. Asp. 1999, 154, 97-101. [CrossRef]

42. Nasluzov, V.; Shor, A.; Romanchenko, A.; Tomashevich, Y.; Mikhlin, Y. DFT+U and low-temperature XPS studies of Fe-depleted chalcopyrite $\left(\mathrm{CuFeS}_{2}\right)$ surfaces: A focus on polysulfide species. J. Phys. Chem. C 2019, 123, 21031-21041. [CrossRef]

43. Peng, Y.; Grano, S. Dissolution of fine and intermediate sized galena particles and their interactions with iron hydroxide colloids. J. Colloid Interface Sci. 2010, 347, 127-131. [CrossRef] [PubMed]

44. Krasowska, M.; Zawala, J.; Bradshaw-Hajek, B.H.; Ferri, J.K.; Beattie, D.A. Interfacial characterisation for flotation: 1. Solid-liquid interface. Curr. Opin. Colloid Interface Sci. 2018, 37, 61-73. [CrossRef]

45. Pawliszak, P.; Zawala, J.; Ulaganathan, V.; Ferri, J.K.; Beattie, D.A.; Krasowska, M. Interfacial characterisation for flotation: 2. Air-water interface. Curr. Opin. Colloid Interface Sci. 2018, 37, 115-127. [CrossRef]

46. Chanturiya, V.A.; Kondratiev, S.A. Contemporary understanding and developments in the flotation theory of non-ferrous ores. Miner. Process. Extr. Met. Rev. 2019, 40, 390-401. [CrossRef]

47. Tarábková, H.; Janda, P. Nanobubble-assisted nanopatterning reveals the existence of liquid quasi-two-dimensional foams pinned to a water-immersed surface. Langmuir 2020, 36, 7200-7209. [CrossRef]

(C) 2020 by the authors. Licensee MDPI, Basel, Switzerland. This article is an open access article distributed under the terms and conditions of the Creative Commons Attribution (CC BY) license (http://creativecommons.org/licenses/by/4.0/). 